\title{
Spontaneous intraamniotic hemorrhage in the second trimester mimicking an abdominal wall defect
}

\author{
Karin duvarı defektini taklit eden ikinci trimester spontan intraamniotik kanama \\ Işık Üstüner ${ }^{1}$, Emine Seda Güvendağ Güven ${ }^{1}$, Gülşah Balık ${ }^{1}$, Şenol Şentürk ${ }^{1}$, Evren Üstüner ${ }^{2}$, Ebru Düşünceli Atman², \\ Ayşe Filiz Avşar ${ }^{3}$ \\ 'Department of Obstetrics and Gynecology, Recep Tayyip Erdoğan University School of Medicine, Rize, Turkey \\ ${ }^{2}$ Department of Radiology, Ankara University School of Medicine, Ankara, Turkey \\ ${ }^{3}$ Department of Obstetrics and Gynecology, Yuldirim Beyazut University School of Medicine, Ankara, Turkey
}

\section{Abstract}

We report here a case of spontaneous intraamniotic haemorrhage in the second trimester which mimicked an abdominal wall defect. The ultrasound and magnetic resonance imaging findings are discussed and a review of the literature regarding differential diagnosis of bleeding and abdominal wall defects is made.

(J Turkish-German Gynecol Assoc 2013; 14: 109-12)

Key words: Diagnostic ultrasound and prenatal diagnosis, intraamniotic haemorrhage, medical problems in pregnancy, premature rupture of membranes

Received: 11 November, 2012

Accepted: 13 December, 2012

\section{Özet}

Biz burada bir karın duvarı defektini taklit eden ikinci trimester spontan intraamniotik kanama olgusunu sunmaktayı. Ultrason ve manyetik rezonans görüntüleme bulguları tartışılmış ve kanama ve karın duvarı defekti ayırıcı tanısı ile ilgili literatür gözden geçirilmiştir.

(J Turkish-German Gynecol Assoc 2013; 14: 109-12)

Anahtar kelimeler: Tanısal ultrasonografi ve prenatal tanı, intraamniotik kanama, gebelikte tıbbi problemler, erken membran rüptürü

Geliş Tarihi: 11 Kasım 2012

Kabul Tarihi: 13 Aralık 2012

\section{Introduction}

Intraamniotic bleeding occurs when a haematoma affecting the intrauterine membranes dissects through the amnion and extends into the amniotic cavity. Abdominal trauma and amniocentesis are the most common aetiologies (1). Herein we report a case of spontaneous intraamniotic haemorrhage in the second trimester which mimicked an abdominal wall defect.

\section{Case Report}

A 24-year-old primigravida female was referred to our clinic at 21 weeks of gestation with the suspicion of an abdominal wall defect. The patient presented first to an outside centre ob/gyn clinic at the $18^{\text {th }}$ week of pregnancy for routine antenatal control. Laboratory results were all normal except for a mild iron deficiency anaemia and high alpha-fetoprotein (AFP) levels [2.6 multiples of median (MoM)] in the triple test. Foetal biometry performed at 18 weeks was also normal. Repeat ultrasonography (US) exam in the $20^{\text {th }}$ gestational week due to high AFP levels revealed a highly echogenic mass within the vicinity of the abdominal wall. The patient was then referred with the pre-diagnosis of a possible foetal abdominal wall defect, likely gastroschisis. There was no history of trauma or genetic amniocentesis. The physical examination of the patient was normal including the blood pressure and pulse readings with no remarkable antenatal or family history.

US showed an echogenic 28x33 mm partially solid and partially cystic heterogeneous mass with unclear margins within the vicinity of the foetal anterior abdominal wall superior to the foetal symphysis pubis. The mass was freely mobile in the amniotic fluid with a cauliflower-like appearance, away from the placenta and close to the umbilical cord insertion of the foetal abdominal wall (Figure 1). There were hyperechogenic fibrin strands and speckles within the amniotic fluid and oligohydramnios was remarkable. The foetal bowels were echogenic. No additional anatomic abnormalities were noted regarding the foetus and foetal biometry was within normal limits. Colour Doppler US examination of the mass revealed no vascularisation and no blood flow. No placenta previa was detected. Due to oligohydramnios, the relationship of the mass with the neighbouring organs was not clear; therefore, foetal magnetic resonance imaging (MRI) and repeat US exam after amnioinfusion was planned. In the differential diagnosis, an abdominal wall defect like gastroschisis or intraamniotic haematoma was entertained. Foetal MRI with fat suppression revealed an intact placenta which ruled out 


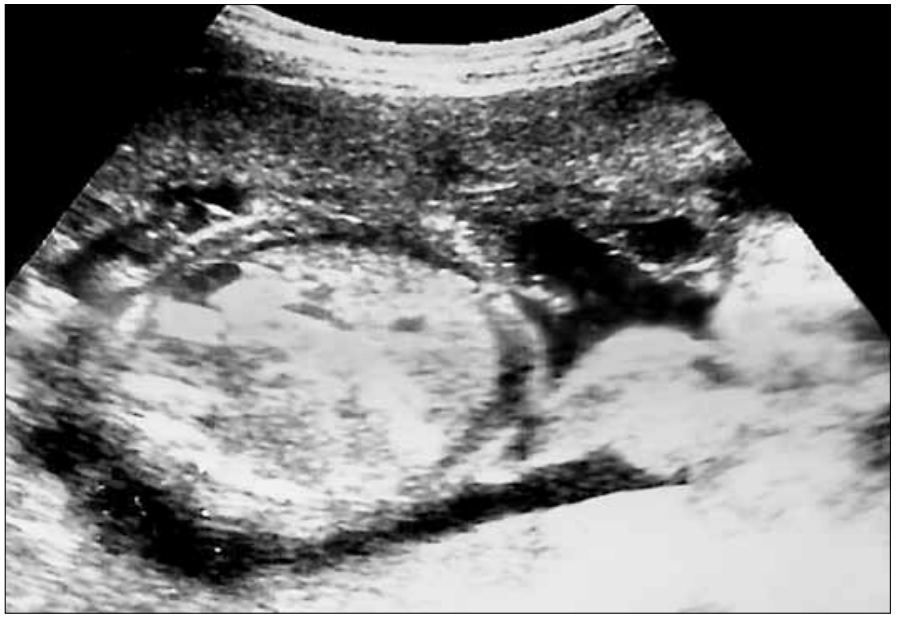

Figure 1. Grey-scale ultrasound depicts an intraamniotic highly echogenic heterogeneous mass anterior to the abdominal wall

placental abruption and an intact abdominal wall which ruled out the wall defects. The intraamniotic mass had a very dark intensity on T2-weighted images (T2WI) and was highly bright on T1WI, suggestive of an early subacute ( $>3$ days) methaemoglobin-containing intraamniotic haematoma (Figures 2-3). In the evening following the MRI examination, the patient had spontaneous premature rupture of membranes (PPROM) and went into premature labour with regular, painful contractions and cervical dilatation; of note, the vaginal amniotic fluid was haemorrhagic and contained blood clots. The family was informed about of the outcomes and a male baby weighing 410 g was delivered.

Postpartum cytogenetic analysis revealed a normal 46 XY karyotype and autopsy findings revealed a normal phenotype. No placental abruption was reported in the pathological examination. Based upon these findings and considering the results of clinical, imaging and pathologic examinations, a final diagnosis of spontaneous intraamniotic haemorrhage which led to PPROM and premature labour was made.

\section{Discussion}

Bleeding in the second and third trimester is a rare and a serious event with a $2 \%$ incidence and causes $25 \%$ of perinatal deaths $(1,2)$. Placenta previa and placental abruption are the most common causes of bleeding. The main clues to placental abruption are pain, haemodynamic deterioration and vaginal bleeding, but neither was detected in this patient (1). The patient in this case was asymptomatic; her vitals were stable throughout the event and bleeding was only noted after PPROM occurred.

Intraamniotic bleeding occurs when a haematoma dissects through the amnion and enters the amniotic cavity. Abdominal trauma and amniocentesis are the most common aetiologies (1). What predisposed this patient to an intraamniotic bleeding is unknown. The patient denied trauma or abuse-related injuries. No adverse history or medical conditions such as hypertension, preeclampsia, blood dyscrasia, vascular malformation, drug use or abuse (e.g. aspirin, coumadin, and anti-

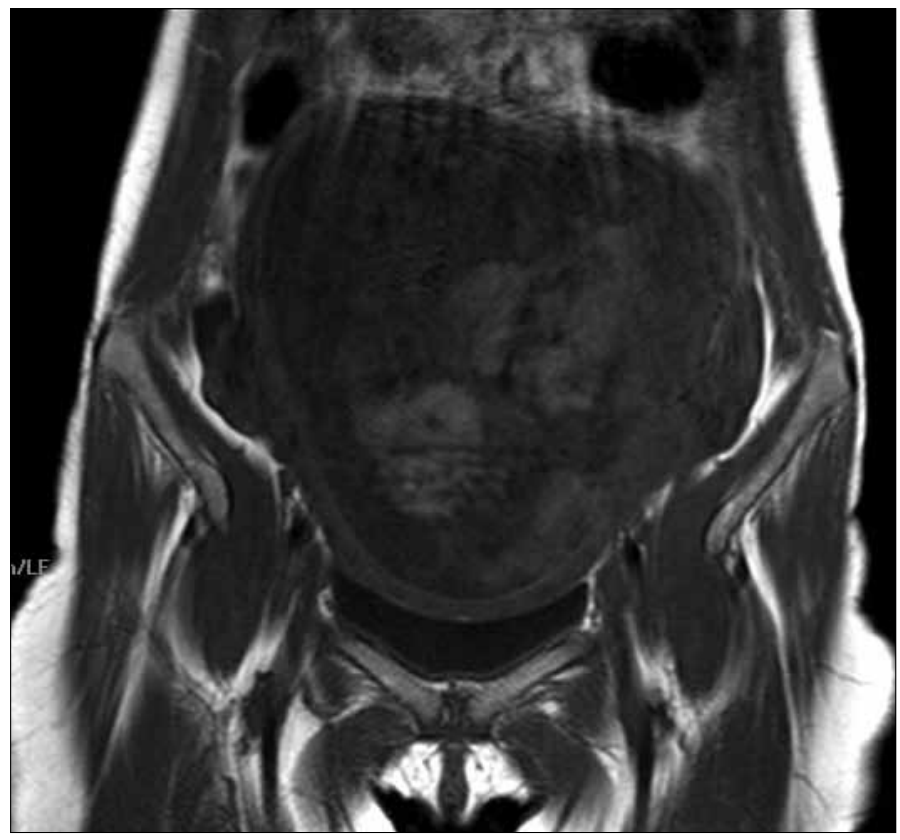

Figure 2. On coronal T1 weighted image blood products within the amniotic fluid appear as hyperintense structures against the dark background of amniotic fluid. Engulfed blood within the intestines of the fetus appears mildly hyperintense too. This finding corresponds to the "echogenic bowel" sign in ultrasound

epileptics) was present. There was no history of amniocentesis and no foetal morphologic or genetic anomaly was detected in the final pathologic examination. No placental inflammation was reported. Unfortunately, the reason for bleeding may remain unknown in 2-3\% of women in the second trimester (2). Although intraamniotic haematomas have a relatively benign course with resolution from 3-10 weeks, adverse events such as preterm labour, congenital anomalies, coagulopathy, IUGR, foetal and maternal mortality and congenital anomalies are increased in case of bleeding $(2,3)$.

Intraamniotic bleeding, either minor or major, develops after almost every amniocentesis procedure (2). Clotted blood forms speckles, echogenic particles, complex fibrin strands or a masslike haematoma. Fresh haematomas are usually anechoic; when organised they become echogenic and with haemolysis become anechoic again (4). Haematomas and fibrin strands may mimic anterior abdominal wall defects especially gastroschisis, amniotic band syndrome, or synechiae. The echogenic blood swallowed by the foetus may also present as "echogenic bowel" or a "gastric pseudomass" $(1,2)$. All of these findings were consistent with our case. The umbilical cord is an unlikely source of intraamniotic bleeding and the cause is often iatrogenic. These haematomas may also appear as anterior abdominal wall defects or placental masses because they are located especially around the umbilical cord insertion sites. Cord haematomas, however, have a grave course and most are haemodynamically instable (1).

MRI is essential in the assessment of bleeding due to its superior spatial resolution, soft tissue contrast, multiplanar imaging capacity and ability to identify and distinguish blood and 


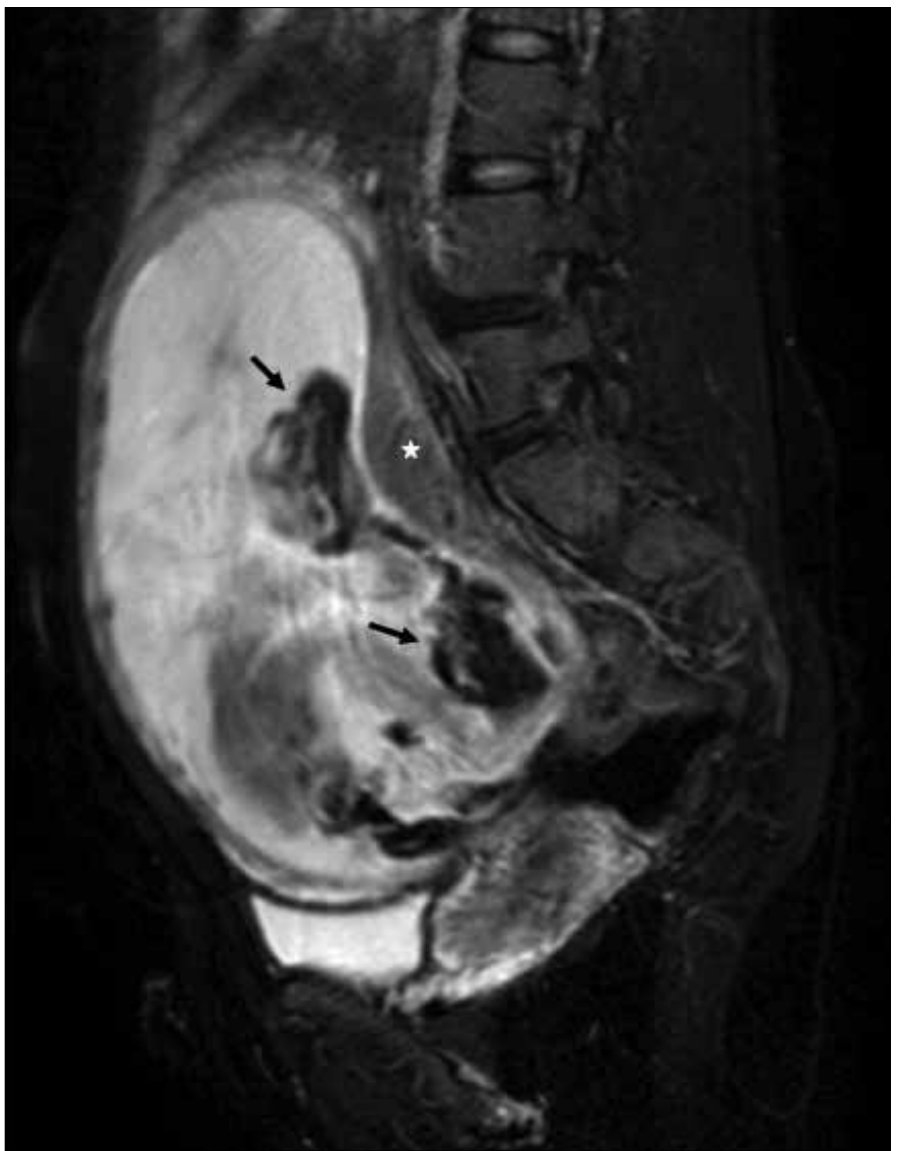

Figure 3. On this T2 weighted fat suppressed sagittal image, an intact placenta is seen on the posterior wall of the uterus (star). Intraamniotic blood degradation products appear as dark intensity mass-like structures in the amniotic fluid (black arrows).

blood products from other fluids. Diffusion WI (DWI) and T1 sequences are especially sensitive to blood. Of note, susceptibility effects of heme products are better displayed by DWI sequences. HASTE and TRUE FISP sequences are also useful when bleeding and ischemia are coexistent. Claustrophobia, high cost and availability may limit the use of MRI $(2,5)$.

The congenital abdominal wall defects include gastroschisis, omphalocele and body stalk anomaly (6). The ultrasonic prenatal diagnosis of these defects is relatively simple and quite possible in the first half of any pregnancy. Care should be taken not to mistake the physiological herniation of the small intestine outside the abdominal cavity between $5^{\text {th }}$ and the $11^{\text {th }}$ weeks of gestation as a wall defect. The sensitivity of antenatal ultrasound examination in detecting omphalocele and gastroschisis are $75 \%$ and $83 \%$ respectively (7). Misdiagnosis of omphalocele as gastroschisis occurs in 5\% of patients (8). This misdiagnosis has serious implications because omphalocele is often associated with chromosomal and other severe anomalies; karyotyping is not indicated in patients with gastroschisis. In one case series, gastroschisis was misdiagnosed as omphalocele at a rate of $14.7 \%$ (9). This misdiagnosis results in unnecessary amniocentesis, which exposes the foetus to the risks and also causes psychological trauma.
There are few data in the literature about false-positive findings of abdominal wall defects in the second trimester. Walkinshaw et al. (9) described a false-positive rate of $5.3 \%$ during the mid1980 s and recently a false-positive rate of $2 \%$ was reported by Kleinrouweler et al. (10). There are some case reports which falsely presumed the presence of omphalocele in association with oligohydramnios (11-13). Diastatic and lax foetal abdominal wall with protrusion of the liver and other organs, abnormal foetal positioning with a decreased amount of amniotic fluid and failure to identify the umbilical cord have all been considered the cause (11-13). These cases are comparable to our case because the relatively small amount of amniotic fluid and compression of the abdominal wall may have caused a false positive diagnosis. Visualisation of the cord vessels and cord entry are essential in the diagnosis and differentiation of abdominal wall defects. Body stalk anomalies where the viscera is located outside the abdominal cavity in proximity with the placenta is also a mimicker, but the presence of other structural anomalies such as malformations of the heart, lungs and limbs helps with differentiation (11). Also in our case, elevated maternal AFP suggested gastroschisis clinically. High AFP is not a specific finding but is also known to increase in cases of bleeding, which may have been a diagnostic clue in this case $(1,14)$.

In conclusion, US has low sensitivity in cases of bleeding. Symptoms may be quite silent as well. Haematomas cause confusion in differential diagnosis and may be mistaken as other entities such as anterior wall defects. Therefore, a high index of suspicion is necessary to establish a correct diagnosis. MRI should be the imaging modality of choice in such cases.

Ethics Committee Approval: N/A.

Informed Consent: Written informed consent was obtained from the patient who participated in this study.

Peer-review: Externally peer-reviewed.

Author contributions: Concept - I.Ü.; Design - I.Ü., G.B., S..Ş., A.F.A.; Supervision - E.S.G.G., A.F.A.;Resource - I.Ü., G.B., Ş.S.., A.F.A.; Materials - I.Ü., G.B., S..Ş., A.F.A.; Data Collection\&/ or Processing - E.Ü., E.D.A.; Analysis\&/or Interpretation - E.Ü., E.D.A.; Literature Search - I.Ü.; Writing - I.Ü., E.Ü., E.D.A.; Critical Reviews - E.S.G.G., A.F.A.

Conflict of Interest: No conflict of interest was declared by the authors.

Financial Disclosure: No financial disclosure was declared by the authors.

\section{References}

1. Trop I, Levine D. Hemorrhage during pregnancy: sonography and MR imaging. AJR Am J Roentgenol 2001; 176: 607-15. [CrossRef]

2. Magann EF, Cummings JE, Niederhauser A, Rodriguez-Thompson D, McCormack R, Chauhan SP. Antepartum bleeding of unknown origin in the second half of pregnancy: a review. Obstet Gynecol Surv 2005; 60: 741-5. [CrossRef]

3. Koifman A, Levy A, Zaulan Y, Harlev A, Mazor M, Wiznitzer A, et al. The clinical significance of bleeding during the second trimester of pregnancy. Arch Gynecol Obstet 2008; 278: 47-51. [CrossRef] 
4. Abu-Yousef MM, Bleicher JJ, Williamson RA, Weiner CP. Subchorionic hemorrhage: sonographic diagnosis and clinical significance. AJR Am J Roentgenol 1987; 149: 737-740. [CrossRef]

5. Masselli G, Brunelli R, Parasassi T, Perrone G, Gualdi G. Magnetic resonance imaging of clinically stable late pregnancy bleeding: beyond ultrasound. Eur Radiol 2011; 21: 1841-9. [CrossRef]

6. Martin RW. Screening for fetal abdominal wall defects. Obstet Gynecol Clin North Am 1998; 25: 517-26. [CrossRef]

7. Barisic I, Clementi M, Häusler M, Gjergja R, Kern J, Stoll Cet al. Evaluation of prenatal ultrasound diagnosis of fetal abdominal wall defects by 19 European registries. Ultrasound Obstet Gynecol 2001; 18: 309-16. [CrossRef]

8. Dillon E, Renwick M. The antenatal diagnosis and management of abdominal wall defects: the northern region experience. Clin Radiol 1995; 50: 855-9.[CrossRef]

9. Walkinshaw SA, Renwick M, Hebisch G, Hey EN. How good is ultrasound in the detection and evaluation of anterior abdominal wall defects? Br J Radiol 1992; 65: 298-301. [CrossRef]
10. Kleinrouweler CE, Kuijper CF, van Zalen-Sprock MM, Mathijssen IB, Bilardo CM, Pajkrt E. Characteristics and outcome and the omphalocele circumference/abdominal circumference ratio in prenatally diagnosed fetal omphalocele. Fetal Diagn Ther 2011;30: 60-9. [CrossRef]

11. Lindfors KK, McGahan JP, Walter JP. Fetal omphalocele and gastroschisis: pitfalls in sonographic diagnosis. AJR Am J Roentgenol 1986; 147: 797-800. [CrossRef]

12. Holland AJ, Ford WD, Linke RJ, Furness ME, Hayward C. Influence of antenatal ultrasound on the management of fetal exomphalos. Fetal Diagn Ther 1999; 14: 223-8. [CrossRef]

13. Bogers H, Exalto N, Cohen-Overbeek TE. Unusual fetal abdominal wall presentation mimicking an abdominal wall defect. J Clin Ultrasound 2011; 39: 410-1. [CrossRef]

14. Tikkanen M, Hämäläinen E, Nuutila M, Paavonen J, Ylikorkala $\mathrm{O}$, Hiilesmaa V. Elevated maternal second-trimester serum alphafetoprotein as a risk factor for placental abruption. Prenat Diagn 2007; 27: 240-3. [CrossRef] 